\title{
Blood pressure crisis following withdrawal of clonidine (Catapres, Catapresan), with special reference to arterial and urinary catecholamine levels, and suggestions for acute management
}

\author{
L. Hansson, M.D.* \\ S. N. Hunyor, M.B., M.R.A.C.P.** \\ S. Julius, M.D. \\ S. W. Hoobler, M.D. \\ Ann Arbor, Mich.
}

$\mathrm{C}$ onidine is an imidazoline derivative with antihypertensive properties. Its mode of action is complex and is as yet not tully understood. Some data ${ }^{1-6}$ indicate that an action on the central nervous system, predominantly at bulbar and diencephalic levels, causes a decreased sympathetic outflow to the cardiovascular system. Other studies $^{7}$ show a direct peripheral effect as well.

Since the introduction of clonidine in Europe in the mid-sixties, several reports have been published regarding its usefulness in the treatment of hypertension. ${ }^{8-12}$ Without trying to evaluate the advantages or disadvantages of clonidine treatment in relation to those of other antihypertensive drugs, it is of utmost importance to be aware of the effects which may follow abrupt cessation of treatment, and which presumably reflect an adrenergic overshoot. There have been some previous attempts to draw attention to the clonidine withdrawal crisis, ${ }^{13,14}$ but on the whole this is a poorly studied phenomenon.

The present study is a description of the blood pressure overshoot and the typical symptoms that are seen when clonidine is stopped abruptly. Attempts have also been made to clarify the underlying mechanism by means of catecholamine determinations in urine and arterial blood before and during the crisis. Finally, suggestions are offered for the acute management of the crisis as well as a possible way to prevent it from occurring.

\section{Materials and methods}

Five patients with severe essential hypertension were studied. (See Table I for

From The Department of Internal Medicine, Hypertension Section, University of Michigan Medical Center, Arn Arbor, Mich.

Supported in part by United States Public Health Service Grant No. 5 M01 RR 42 to the Clinical Research Unit, University Hospital.

Received for publication July 17, 1972.

Reprint requests to: Dr. S. W. Hoobler, Department of Internal Medicine, University Hospital, Ann Arbor, Mich. 48104.

* Present address: Department of Internal Medicine, Sahlgrenska Hospital, University of Gothenburg, Gothenbirg, Sweden.

** Dr. Hunyor was a recipient of a Travel Grant of the National Heart Foundation of Australia. His present address is: Hallstrom Institute of Cardiology, Royal Prince Alfred Hospital, Sydney, Australia. 
Table I. Patient information

\begin{tabular}{|c|c|c|c|c|c|c|c|c|}
\hline $\begin{array}{l}\text { Patient } \\
\text { No. and } \\
\text { initials }\end{array}$ & $\begin{array}{l}\text { Age } \\
(y r .)\end{array}$ & $\operatorname{Sex}$ & Diagnosis & $\begin{array}{c}\text { Fundi } \\
\left(K . W . B .^{*}\right)\end{array}$ & $L V H \dagger$ & $\begin{array}{c}\text { Serum } \\
\text { creatinine } \\
(m g . / 100 m l .)\end{array}$ & $\begin{array}{l}\text { Dosnge of } \\
\text { clonidine } \\
\text { (mg. daily) }\end{array}$ & $\begin{array}{l}\text { Blood pressure } \\
\text { on clonidine } \\
\text { (mm. Hgaverage } \\
\text { of } 7 \text { recordings) }\end{array}$ \\
\hline 1. G. Mc. & 38 & M & Essential hypertension & II & yes & 1.9 & 1.6 & $146 / 106$ \\
\hline 2. R. E. & 40 & M & Essential hypertension & II & yes & 1.5 & 2.4 & $154 / 113$ \\
\hline 3. P. C. & 29 & $\mathrm{~F}$ & Essential hypertension & I & no & 1.2 & 1.6 & $126 / 93$ \\
\hline 4. G. M. & 43 & M & Essential hypertension & II & yes & 1.9 & 1.2 & $170 / 115$ \\
\hline 5. L. C. & 53 & M & Essential hypertension & II & no & 1.3 & 0.3 & $157 / 92$ \\
\hline
\end{tabular}

*Hypertensive changes according to the Keith-Wagener-Barker classification.

tLeft ventricular hypertrophy on ECG or chest $x$-ray.

clinical details.) All were on chronic treatment with clonidine ( 2 to 4 years) and all had a documented previous blood pressure overshoot that occurred when treatment had been stopped temporarily for various reasons.

After informed consent was obtained, the patients were hospitalized in the Clinical Research Unit. While still on their regular dosage of clonidine, ( 0.3 to $2.4 \mathrm{mg}$. daily), baseline studies of blood pressures were performed. Arterial and urinary catecholamines were determined with the fluorimetric technique, ${ }^{15}$

At 10:00 P.M. on day 3, placebo was substituted for clonidine. It was planned to take counteractive measures if the blood pressure rose excessively. During the crisis, urine was to be collected for catecholamine determinations and immediately before administering the alpha and beta receptor blockers an arterial blood sample was to be obtained, also for catecholamine determinations. Finally, we had decided to reinstitute clonidine, should the acute administration of propranolol and phentolamine prove unsuccessful in the management of the crisis. If, on the other hand, the crisis could be overcome by these means, chronic oral treatment with propranolol and hydralazine was to be instituted, as the experience with this combination is clearly positive..$^{16,17}$

As the study proceeded, two modifications to the above plan were introduced. Patient No. 3 was given oral propranolol and dibenzyline from the onset of withdrawal symptoms.

Finally, having gained sufficient expe- rience with Patients 1 through 4 , we attempted to alter the overshoot by pretreatment with a catecholamine depleting agent. Consequently, the fifth patient on the study received reserpine $1.0 \mathrm{mg}$. intramuscularly twice daily for three days before the withdrawal of clonidine. There is evidence in man that such a dosage scheme is more than adequate to effect a significant catecholamine depletion. ${ }^{18}$

Statistical comparison of blood pressure and catecholamine level was made by Student's $t$ test of paired observations.

\section{Results}

All five patients noted the change from clonidine to placebo within 2 to 3 hours. Initially they complained of restlessness and those who had already gone to sleep woke up. None of the five was able to go to sleep after that. Gradually an increasingly severe headache appeared and in combination with this nausea and sometimes increased salivation were noted. Tremor and restlessness were obvious in all (see Table II for a complete list of symptoms).

In Patients 1 through 4, there was a marked rise of blood pressure, from an average of $149 / 103 \mathrm{~mm}$. $\mathrm{Hg}$ (average of all four consecutive readings during the day before withdrawal) to an average maximum of $216 / 161 \mathrm{~mm}$. Hg at an average postwithdrawal time of 12 hours. Compared to prior blood pressure readings there was a significant systolic blood pressure rise $(67$ $\mathrm{mm} . \mathrm{Hg}, \mathrm{p}<0.01)$ and a significant diastolic rise $(58 \mathrm{~mm}$. $\mathrm{Hg}, \mathrm{p}<0.01)$. At the time when counteractive measures were undertaken, the patients were markedly 
Table II. Symptoms following clonidine withdrawal

\begin{tabular}{|c|c|c|c|c|c|c|c|c|c|c|}
\hline $\begin{array}{l}\text { Patient } \\
\text { No. and } \\
\text { initials }\end{array}$ & $\begin{array}{c}\text { Insom- } \\
\text { nia }\end{array}$ & $\begin{array}{c}\text { Vivid } \\
\text { dreams }\end{array}$ & $\begin{array}{l}\text { Head- } \\
\text { aches }\end{array}$ & $\begin{array}{l}\text { Nausea/ } \\
\text { anorexia }\end{array}$ & Tremor & $\begin{array}{c}\text { Restless- } \\
\text { ness }\end{array}$ & $\begin{array}{c}\text { Saliva- } \\
\text { tion }\end{array}$ & $\begin{array}{l}\text { Hic- } \\
\text { cups }\end{array}$ & $\begin{array}{c}\text { Stomach } \\
\text { pains }\end{array}$ & $\begin{array}{l}\text { Muscle } \\
\text { pains }\end{array}$ \\
\hline $\begin{array}{l}\text { 1. G. Mc. } \\
\text { 2. R. E. } \\
\text { 3. P. C. } \\
\text { 4. G. M. } \\
\text { 5. L. C. }\end{array}$ & $\begin{array}{r}++ \\
++ \\
++ \\
++ \\
+\end{array}$ & $\begin{array}{c}+++ \\
- \\
- \\
+++\end{array}$ & $\begin{array}{c}+++ \\
+++ \\
++ \\
++ \\
-\end{array}$ & $\begin{array}{r}++ \\
+ \\
++ \\
+ \\
+\end{array}$ & $\begin{array}{r}++ \\
+ \\
++ \\
++ \\
+\end{array}$ & $\begin{array}{r}+++ \\
++ \\
+++ \\
++ \\
+\end{array}$ & $\begin{array}{l}+ \\
+ \\
- \\
-\end{array}$ & $\begin{array}{c}t+ \\
t+ \\
++ \\
+\end{array}$ & $\begin{array}{l}\frac{t}{t+} \\
- \\
-\end{array}$ & $\begin{array}{c}+ \\
- \\
+++ \\
-\end{array}$ \\
\hline
\end{tabular}

Symbols: $+++=$ marked $;+=$ moderate; $+=$ mild $;-=$ not noted.

distressed, complaining of severe headache, nausea, and tremor.

When propranolol was given (Patients 1, 2, and 4) $0.2 \mathrm{mg}$. per kilogram of body weight over 2 to 4 minutes, there was an almost immediate relief of the restlessness and tremor, with little or no effect on the blood pressure. However, when phentolamine was administered intravenously in 5 to $10 \mathrm{mg}$. doses at successive five minute intervals to a total of 20 to $30 \mathrm{mg}$., there was a significant drop of the blood pressure to an average of $169 / 117 \mathrm{~mm}$. Hg. The systolic drop averaged $47 \mathrm{~mm}$. $\mathrm{Hg}(\mathrm{p}<$ 0.01 ) and the diastolic drop was $44 \mathrm{~mm}$. $\mathrm{Hg}$ $(\mathrm{p}<0.02)$ (Fig. 1).

In Patient No. 3 the blood pressure peak was $200 / 135 \mathrm{~mm}$. IIg (as compared to the average of $120 / 80 \mathrm{~mm}$. Hg during the preceding day). It was possible over 48 hours to gradually reduce the blood pressure toward the initial levels by oral propranolol $40 \mathrm{mg}$. four times daily and dibenzyline $20 \mathrm{mg}$. four times daily.

Patient No. 5, who was pretreated with reserpine in order to obtain depletion of his catecholamine depots, had a decidedly milder course after the withdrawal of clonidine. Although he complained of the same symptoms as Patients 1 to 4 , his symptoms were clearly of a milder degree. The blood pressure rise was also less marked, from $130 / 95 \mathrm{~mm}$. Hg to $175 / 120 \mathrm{~mm}$. Hg at 12 hours, and no acute treatment with intravenous propranolol or phentolamine was considered necessary.

The average heart rate in all patients increased from 73 beats per minute to 85 beats per minute (not statistically significant).
The average total catecholamine levels in urine rose from $32 \mu \mathrm{g}$ per 24 hours to 112 $\mu \mathrm{g}$ per 24 hours $(\mathrm{p}<0.02)$, while the arterial total catecholamines rose from 0.52 $\mu \mathrm{g}$ per liter to $1.0 \mu \mathrm{g}$ per liter (not statistically significant) (see Figs. 2 and 3 ).

\section{Discussion}

Clonidine is a clearly useful antihypertensive drug, as has been pointed out in several studies. ${ }^{8-12}$ Unlike most other drugs, however, it may cause severe withdrawal symptoms when it is withheld abruptly. Aside from the rapid and severe rise of the blood pressure, there is a rather constant array of symptoms such as insomnia, restlessness, tremor, and headache, which makes the crisis look very similar to that seen in pheochromocytoma. This picture plus the demonstrated increase in catecholamine excretion (274 to $913 \mu \mathrm{g}$ per 24 hours) and the positive response to adrenergic alpha and beta receptor blockers, seem indeed to indicate a markedly increased sympathetic discharge. However, the occurrence of stomach pains and rather pronounced nausea suggest to us that there is not only increased sympathetic discharge but increased parasympathetic activity as well.

As all of our patients were selected for the present study because of a previously documented blood pressure overshoot following clonidine withdrawal, we are not able to draw conclusions regarding the frequency with which a withdrawal crisis will occur. On the other hand, our findings seem to indicate that the phenomenon is reproducible. The patients experiencing crisis were on long-term therapy. We have 


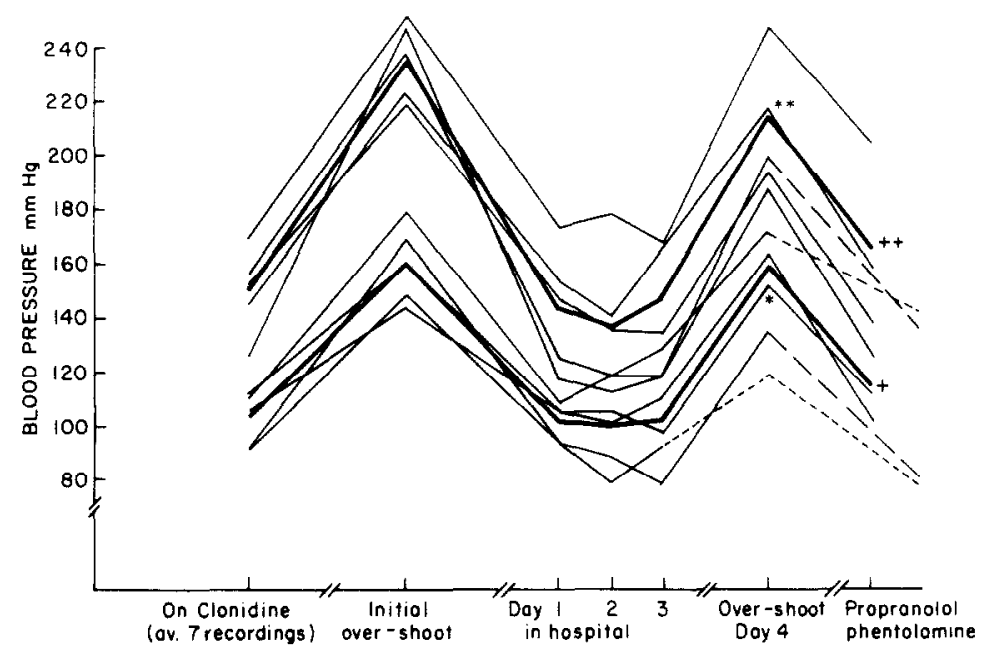

Fig. 1. Blood pressures before and during the study. Heavy lines indicate the average blood pressure. - - refers to patient No. 3. - - refers to patient No. 5 who was pretreated with reserpine. ${ }^{* *}$ Systolic blood pressure rise $67 \mathrm{~mm} . \mathrm{Hg}, \mathrm{p}<0.01$. *Diastolic blood pressure rise $58 \mathrm{~mm}$. Hg, $\mathrm{p}<0.01$. ††Systolic blood pressure fal $47 \mathrm{~mm}$. Hg, p $<0.01$. †Diastolic blood pressure fall $44 \mathrm{~mm} . \mathrm{Hg}, \mathrm{p}<0.02$.

not systematically studied the withdrawal phenomenon on short-term therapy ( 1 to 2 months) but abortive attempts to treat with clonidine some hypertensive patients, plus the withdrawal of therapy reported in other studies with clonidine (see all studies where clonidine treatment has been followed by placebo therapy) suggest that the crisis is less dramatic after short-term therapy. Furthermore, it is to be emphasized that in this study relatively large doses of the drug were abruptly withdrawn. We have had less experience with tapering the dosage, but if the blood pressure rise can be counteracted, the other symptoms of crisis do not appear until complete withdrawal is attempted and they may probably be prevented by propranolol or reserpine pretreatment.

In regard to the acute management of the crisis, the logical treatment of course is reinstitution of clonidine. As an alternative, in an emergency, intravenous propranolol and phentolamine are useful.

If a planned withdrawal of clonidine is to be undertaken, the data suggest that depletion of catecholamine storages, as with reserpine pretreatment, would be a logical step prior to clonidine withdrawal. Although our experience is limited, the results show that this course of action was hclpful in mitigating withdrawal symptoms, having at least a partial effect. Thus $\mathrm{Pa}$ - tient No. 5, who was pretreated with reserpine, showed a much smaller blood pressure peak $(175 / 120 \mathrm{~mm}$. $\mathrm{Hg})$ than at the previously recorded overshoot $(240 / 150$ $\mathrm{mm}$. $\mathrm{Hg}$ ). He also seemed to suffer considerably less from the withdrawal, although he experienced the same kind of symptoms (Table I).

Finally, after the acute management of the crisis, it has been possible to control the blood pressure in Patients 1, 4, and 5 with oral propranolol and hydralazine at the same or lower blood pressure levels as during clonidine treatment.

\section{Conclusions}

The following conclusions seem warranted:

1. Acute withdrawal of clonidine may cause a severe and potentially fatal blood pressure overshoot.

2. The accompanying symptoms as well as the increased catecholamine excretion and the response to adrenergic blockers indicate an increased sympathetic discharge. This is possibly accompanied by an increased parasympathetic activity.

3. In the acute crisis, combined alpha and beta receptor blockade with phentolamine and propranolol seems useful.

4. Depletion of catecholamine stores, e.g., with reserpine prior to withdrawal of clonidine, may reduce the withdrawal 


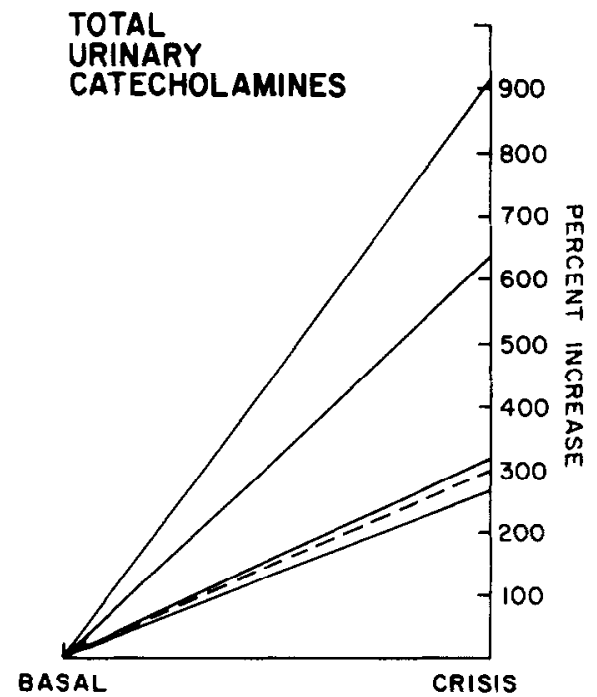

Fig. 2. Per cent increase of total urinary catecholamines. - - - refers to patient No. 5, who was pretreated with reserpine.

symptoms and the blood pressure rise.

In view of our findings, it is obvious that the patients need to be informed about the possible dangers of suddenly stopping clonidine treatment. They should be warned always to have an alternate supply for emergencies should they be on vacations or in places where the drug may not be easily available. Withdrawal of clonidine prior to surgery is not recommended since a crisis may appear about 12 hours later and interfere seriously with postoperative care. If all oral medication must be withdrawn, clonidine should be supplied intravenously or by gastric tube or plans should be made to maintain the patient on propranolol-phentolamine during the postoperative interval.

Finally, this study has shown that if patients on long-term clonidine therapy are to be considered for conversion to other forms of antihypertensive management, the transition must be managed carefully using reserpine, propranolol, or other antihypertensive agents with considerable attention to the detailed day-to-day blood pressure.

\section{Summary}

In five patients with severe essential hvpertension, placebo was substituted after 24 to 48 months of treatment with clonidine and a diuretic. In the present study, four of the patients developed a marked blood pressure rise following withdrawal of cloni-

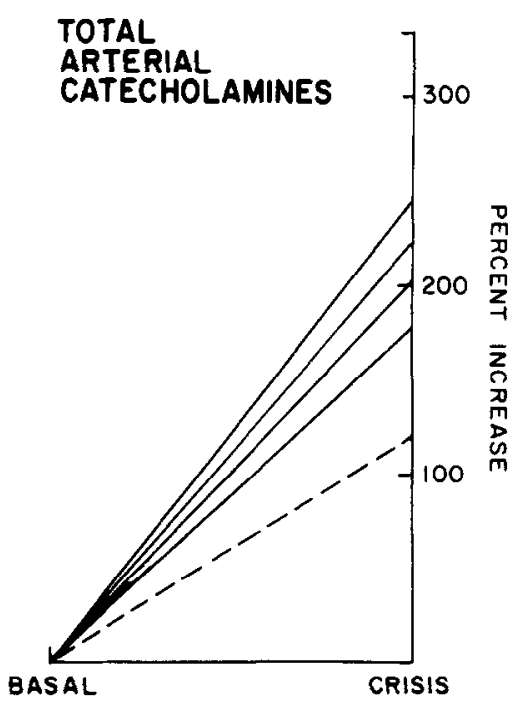

Fig. 3. Per cent increase of total arterial catecholamines. - - refers to patient No. 5, who was pretreated with reserpine.

dine which was rapidly reversed by intravenous administration of propranolol 0.2 mg. per kilogram of body weight and phentolamine 20 to $30 \mathrm{mg}$. The fifth patient was pretreated with reserpine $2.0 \mathrm{mg}$. intramuscularly for three days prior to withdrawal of clonidine, and the blood pressure rise which he experienced was far less impressive. All patients experienced similar "withdrawal" symptoms, consisting of headaches, insomnia, restlessness, tremor, and nausea.

Catecholamines were determined in arterial blood and urine, before and during the overshoot. They revealed a marked increase, particularly in the urine samples, consistent with the appearance of a hyperadrenergic state.

\section{REFERENCES}

1. Kobinger, W., and Walland, A.: Kreislanfuntersuchungen mit 2-(2,6-dichlorophenylamino)-2imidazoline hydrochlorid, Arzneim. Forsch. $17: 292,1967$.

2. Sattler, R. W., and van Zweiten, P. A.: Acute hypotensive action of 2-(2,6-dichlorophenylamino)-2 imidazoline hydrochloride (ST 155) after infusion into the cat's vertebral artery. Eur. J. Pharmacol. 2:9, 1967.

3. Schmitt, H., Schmitt, H., Boissier, I. R., and Guidicelli, J. F.: Centrally mediated decrease in sympathetic tone induced by 2-(2,6-dichlorophenylamino)-2 imidazoline (ST 155, Catapresan), Eur. J. Pharmacol. 2:147, 1967.

4. Rand, M. J., and Wilson, J.: Mechanisms of the 
pressor and depressor actions of ST 155 (2-[2,6dichlorophenylamino]-] imidazoline hydrochloride, Catapres), Eur. J. Pharmacol. 3:27, 1968.

5. Nayler, W. G., Price, J. M., Swann, J. B., McInnes, I., Race, D., and Lowe, T. E.: Effect of the hypotensive drug, ST 155, on the heart and the peripheral circulation, J. Pharmacol. Exp. Ther. 164:45, 1968.

6. Shaw, J., Hunyor, S. N., and Korner, P. I.: Sites of central nervous action of clonidine on reflex autonomic function in the unanesthetised rabbit, Eur. J. Pharmacol. 15:66, 1971.

7. Shaw, J., Hunyor, S. N., and Korner, P. I.: The peripheral circulatory effects of clonidine and their role in the production of arterial hypertension, Eur. J. Pharmacol. 14:101, 1971.

8. Bergström, J., Bergquist-Poppen, M., and Bucht, H.: Erste Klinische Ehrfahrungen mit einer neuen blutdrucksenkend Substanz bei schweren Hypertoniformen, Arzneim. Forsch. $16: 1606,1966$.

9. Smet, G., Hoobler, S. W., Sanbar, S., and Julius, S.: Clinical observations on a new antihypertensive drug, 2-(2,6-dichlorophenylamine) -2-imidazoline hydrochloride, AM. Heart J. 77:473, 1969.

10. Phelan, E. L., McGregor, D. D., Laverty, R., Taylor, K. M., and Smirk, H.: Properties of Catapres, a new hypotensive drug, N. Z. Med. J. $66: 864,1967$.

11. Björk-von Bahr, S.: Blodtryckssänkande be- handling met ett imidazolin derivat, Lakartid. ningen $66: 3701,1969$.

12. Hoobler, S. W., and Sagastume, E.: Clonidine hydrochloride in the treatment of hypertension, Am. J. Cardiol. 28:67, 1971.

13. Hoobler, S. W.: in Conolly, M. E., ed.: Catapres in hypertension, Symposium held at Royal College of Surgeons, London, 1969, Butterworth and Co., Ltd., p. 216.

14. Hökfelt, B., Hedeland, H., and Dymling, J. F.: Studies on catecholamines, renin and aldosterone following Catapresan (2-[2,6-dichlor-phenylamine]-2 imidazoline hydrochloride) in hypertensive patients, Eur. J. Pharmacol. 10:389, 1970.

15. Euler, U. S. von, and Lishajko, F.: Imprcved technique for the fluorimetric estimation of catecholamines, Acta Physiol. Scand. 51:348, 1961.

16. Hansson, L., Olander, R., Åberg, H., Malmcrona, R., and Westerlund, A.: Treatment of hypertension with propranolol and hydralazine, Acta Med. Scand. 190:531, 1971.

17. Zacest, R., Gilmore, E., and Koch-Weser, J.: Treatment of essential hypertension with combined vasodilation and beta-adrenergic blockade, N. Engl. J. Med. 286:617, 1972.

18. Abboud, F. M., and Eckstein, J. W.: Effects of small oral doses of reserpine on vascular responses to tyramine and norepinephrine in man, Circulation 24:219, 1964. 